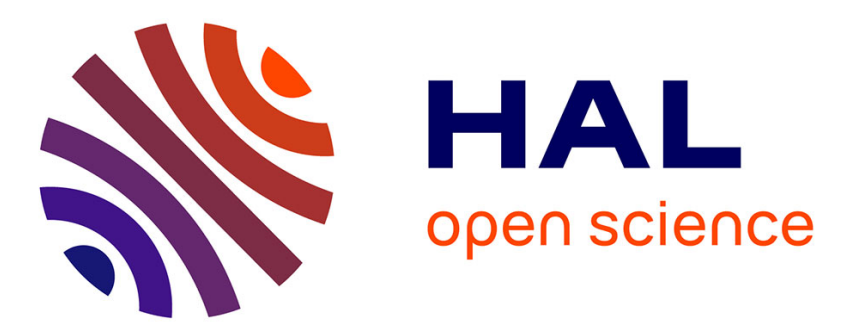

\title{
The Invention of New Methodologies: An Opportunity for Dating Natural Products
}

\author{
Marion Barbazanges, Louis Fensterbank
}

\section{To cite this version:}

Marion Barbazanges, Louis Fensterbank. The Invention of New Methodologies: An Opportunity for Dating Natural Products. SYNLETT, 2018, 29 (16), pp.2108-2116. 10.1055/s-0037-1609627 . hal-01955893

\section{HAL Id: hal-01955893 https://hal.sorbonne-universite.fr/hal-01955893}

Submitted on 14 Dec 2018

HAL is a multi-disciplinary open access archive for the deposit and dissemination of scientific research documents, whether they are published or not. The documents may come from teaching and research institutions in France or abroad, or from public or private research centers.
L'archive ouverte pluridisciplinaire $\mathbf{H A L}$, est destinée au dépôt et à la diffusion de documents scientifiques de niveau recherche, publiés ou non, émanant des établissements d'enseignement et de recherche français ou étrangers, des laboratoires publics ou privés. 


\section{The Invention of New Methodologies, An Opportunity for Dating Natural Products}

\author{
Marion Barbazanges ${ }^{a}$ \\ L. Fensterbank*a \\ a Sorbonne Université, CNRS, Institut Parisien de Chimie \\ Moléculaire (UMR 8232), 4 place Jussieu, F-75005 Paris, \\ France \\ louis.fensterbank@sorbonne-universite.fr
}

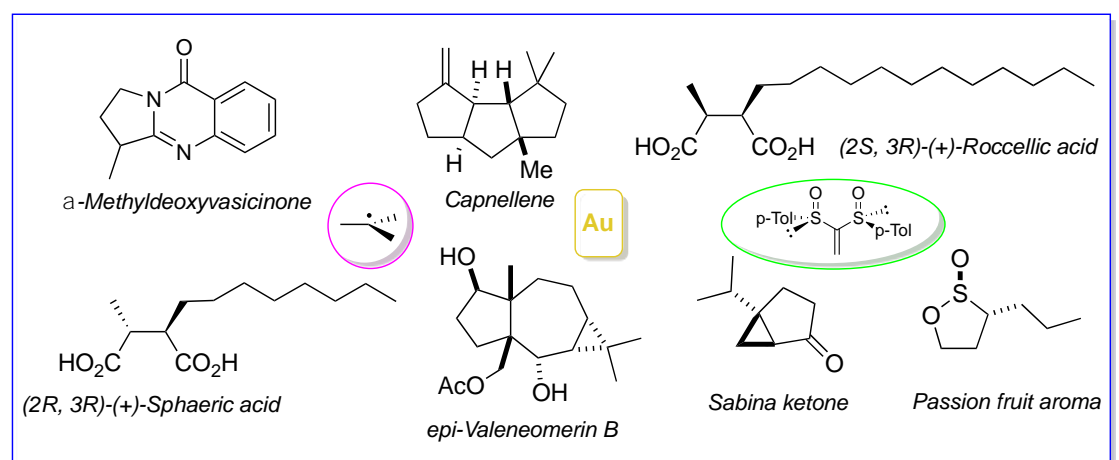

Abstract: This account surveys almost two decades of methodological developments and their straightforward application to the total synthesis of simple natural products. The main directions covered include radical chemistry and cascades, electrophilic catalysis based on coinage metals and asymmetric synthesis based on bis(sulfoxides) auxiliaries.

Table of contents:

1. Introduction

2. Radical cascades

3. Electrophilic catalysis based on platinum(II) and gold(I) complexes

4. From alkylydene bis(sulfoxides) to chiral carboxylic acids

5. Conclusion and perspectives

Key words radical chemistry, gold catalysis, natural products, total synthesis, asymmetric synthesis, bis(sulfoxides)

\section{Introduction}

There are clearly two types of organic synthetic chemists who like to deal with natural products. The first group is entirely focused on a target as an alpinist chooses a mountain to climb and any pathway would work as long as the goal is reached. The second group is more opportunistic and will aim at illustrating the versatility of its newly developed methodologies through the total synthesis of a relevant natural compound. While it is not question here to judge which approach scientifically makes more sense, since it is also highly dependent on the target and on the involved methodologies, it is rather clear that each party enriches the other. In this context, our laboratory has, over the last decade, participated to several important synthetic methodology developments and adapted them to the straightforward synthesis of natural compounds. Based on radical cascades, electrophilic catalysis with platinum and gold complexes or Michael additions on alkylidene bis-sulfoxides, these casual datings with natural products have been particularly stimulating. This account surveys the different key methodologies which have been utilized over the last twenty years, and their specific applications.

\section{1. $N$-cyanamides}

Based on the legacy of the Max Malacria group, ${ }^{1}$ a strong expertise in radical chemistry and cascades was present in our laboratory and generally involved polyunsaturated hydrocarbon substrates. In the early 2000s', the interest of the group shifted to new partners and notably heteroatomic functions to provide accesses to valuable scaffolds. $N$-Ynamides ${ }^{2}$ and $N$-cyanamides ${ }^{3}$ appeared rapidly of great appeal since they can serve as relay functions by being both a radical acceptor on a sp-hybridized carbon center and then a radical partner through a highly reactive vinyl or iminyl radical (Scheme 1). Based on this principle, using an aryl, vinyl or alkyl radical trigger, some new types of tandem cyclizations could be worked out to deliver guanidine and quinazolinone platforms. ${ }^{4}$ In the latter case, by engaging the adequate alkyl radical precursor which meant playing with the $R_{1}$ and $R_{2}$ substituents on substrates of type $\mathbf{1}$, the total synthesis of deoxyvasicinone, a natural alkaloid isolated from Adhatoda vasica ${ }^{5}$ with anti-depressive, antibacterial and anti-inflammatory properties, ${ }^{6}$ was achieved. Similarly, with $\mathrm{n}=2$ for the tether length, mackinazolinone was obtained. Mackinazolinone was isolated in 1965 in New Guinea from the leaves of Mackinlaya subulata ${ }^{7}$ and it exhibits a large spectra of pharmaceutical activities. ${ }^{8}$

The cyclization tandem begins respectively with a 5-exo-dig or a 6-exo-dig cyclization and, as generally observed, a stoichiometric amount of AIBN is required to ensure rearomatization after the aromatic homolytic substitution. ${ }^{9}$ At the occasion of this study, we also synthesized the medicinally relevant $\alpha$-methyldeoxyvacisinone as well as the quaternary $\alpha, \alpha^{\prime}$-dimethyl analogue. 


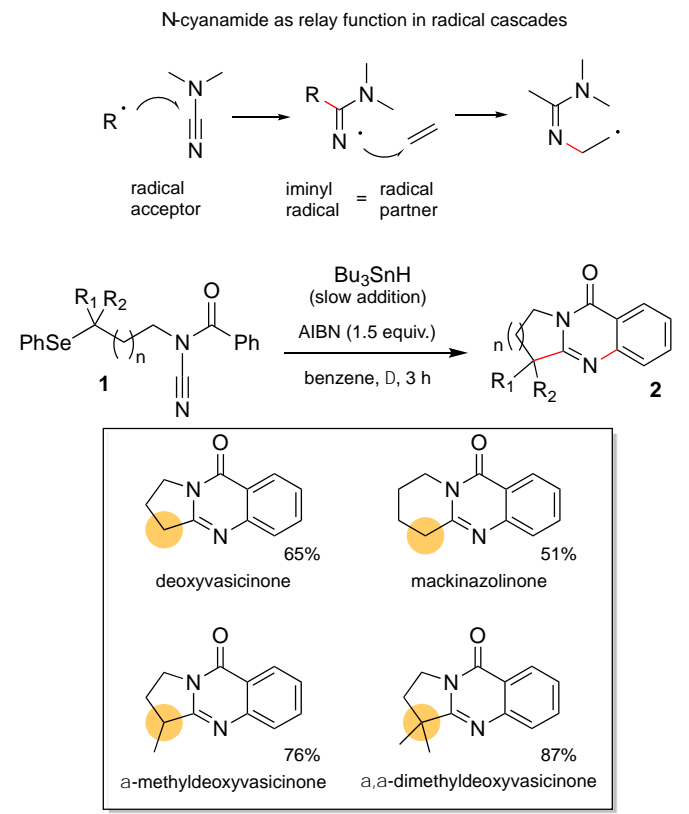

Scheme 1 Radical cascades leading to vasicinones

\subsection{Homolytic substitution at sulfur atom to give sultines}

Homolytic substitution is an intriguing radical reaction ${ }^{10}$ which has been certainly underused in the context of total synthesis. Connected to a more general interest in sulfur chemistry (see also section 4.), we went one step forward within sulfur reactivity and turned our attention towards homolytic substitution at the sulfur atom to obtain cyclic sulfinates and sulfonamides. ${ }^{11,12}$ Indeed, these moieties are lactone and lactame bioisosteres ${ }^{13}$ that are found in natural products ${ }^{14}$ and have been used as imaging agents. ${ }^{15}$ Moreover, they are versatile synthetic intermediates. Our design was to involve substrates which would incorporate a highly reactive radical trigger and a good radical leaving group. Of particular interest was to study the stereochemical outcome at the sulfur atom and the diastereoselectivity of the transformation. Thus, we focused on the treatment of aryl bromides $\mathbf{3}$ with tributyltin hydride in the presence of AIBN as a radical initiator. The generated aryl radical adds to the sulfinate moiety to yield the desired sultines $\mathbf{4}$ by ejection of the stable tertiary tert-butyl radical (Scheme 2). By cyclizing enantioenriched sultinamides and sultines such as $(R)$-3a, we showed that these transformations occurred with total inversion of configuration at sulfur (sultine (S)-4e).

That is in agreement with an intramolecular homolytic substitution mechanism which proceeds through a transition state in which the attacking and leaving radicals adopt a near collinear arrangement as suggested by DFT calculations from the Schiesser group. ${ }^{16}$ Cyclization of a secondary alkyl radical was challenging since the bond dissociation energy (BDE) gain is lower in this case. Moreover, the sulfur atom is now prostereogenic and the cyclization can thus lead to diastereoisomers. We showed that homolytic substitution of primary, secondary or tertiary alkyl radical generated from bromide (for sulfinates) or selenide (for sulfinamides) 5 led predominantly to the trans sultines and sultinamides $\mathbf{6}$, in a ratio ranging from 2:1 to $>25: 1$ depending on the steric hindrance of the $\mathrm{Y}^{1}$ and $\mathrm{Y}^{2}$ substituents (Scheme 2, Eq. 3). This methodology provided access to natural product sultine $\mathbf{6 a}$ that can be found in extracts of passion fruit. ${ }^{14}$ When alkyl sufinate $\mathbf{5 a}$ was treated by TTMSS as the reducing agent in the presence of a catalytic amount of AIBN, the corresponding secondary radical leads to sultine $\mathbf{6 a}$ of trans configuration in a 2:1 diastereomeric ratio (99\%) (Scheme 2, Eq. 4). ${ }^{11}$

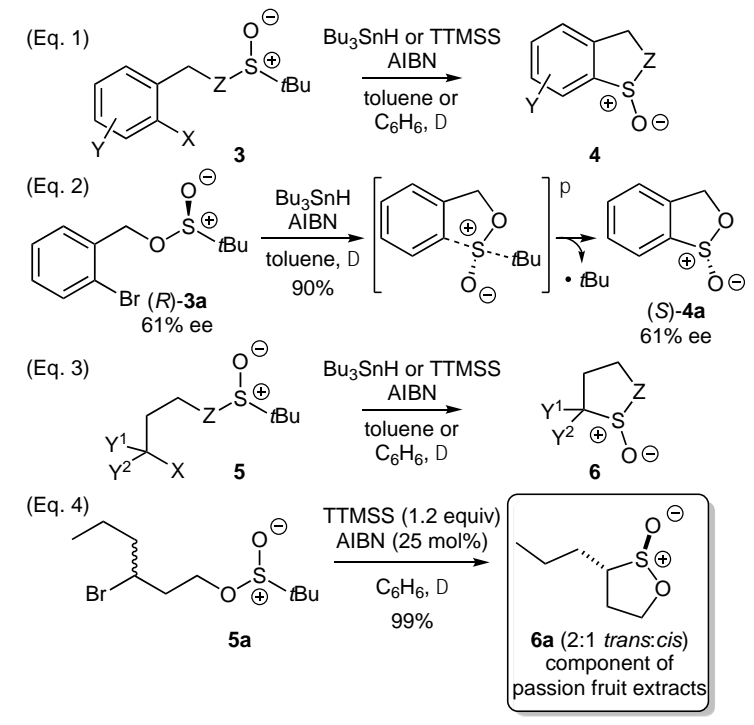

Scheme 2 Radical cyclization towards sultines and sulfinamides. Application in total synthesis

\section{Electrophilic catalysis based on platinum(II) and gold(I) complexes}

Another domain of predilection of our laboratory has concerned organometallic catalysis based on the engagement of polyunsaturated substrates (enynes, diynes, allenynes). The logical move in the 2000s' was to experiment the emerging use of electrophilic metals such as platinum(II) ${ }^{17}$ and gold(I) ${ }^{18}$ complexes in order to generate molecular complexity. ${ }^{19}$ Thus, in 2002, in collaboration with the Marco-Contelles group, we evidenced a fascinating effect of an oxygenated group at the propargylic position in the $\mathrm{PtCl}_{2}$-catalyzed cycloisomerization of dienyne precursors. ${ }^{20}$ In typical conditions ( $5 \mathrm{~mol} \% \mathrm{PtCl}_{2}$ in toluene at $80^{\circ} \mathrm{C}$ ), methoxyether $\mathbf{7}$ led to the highly congested tetracyclic derivative $\mathbf{8}$ as a single diastereomer, which displays two fused cyclopropane moieties. Formally, product $\mathbf{8}$ originates from the transformation of the central alkyne moiety into a bis carbene entity, a reactivity previously reported by Chatani and Murai, ${ }^{21}$ and that was supported by calculations. ${ }^{22}$ In contrast, ester precursor 9 provided the very major product 10 featuring a 1,2-acetate migration concomitant with the formation of a cyclopropane (Scheme 3). This ability of a propargyl acetate to migrate in the presence of electrophilic metals was reminiscent of the transformation of 1-ethynyl-2-propenyl acetates into 2-cyclopentenones in the presence of palladium(II), also referred now as the Ohloff-Rautenstrauch rearrangement. ${ }^{23}$ It has also proved to provide a very solid route to click a propargyl acetate with an alkene to form a cyclopropyl group adjacent to an enolester moiety whether inter- or intramolecularly. ${ }^{19 b, 24,25}$ 
In terms of mechanism, initial formation of an electrophilic alkyne- $\mathrm{PtCl}_{2}$ coordination complex of type $\mathbf{A}$ triggers a nucleophilic attack of the richest partner: an alkene, to give platinacyclopropyl carbene $\mathbf{B}$; or an $O$-acyl group, to generate intermediates $\mathbf{C}$ and $\mathbf{D}$ through migration of the ester. Importantly, in the case of ester substrates, chirality transfer from the propargylic position has been observed, suggesting a rather concerted cycloisomerization mechanism. ${ }^{26}$

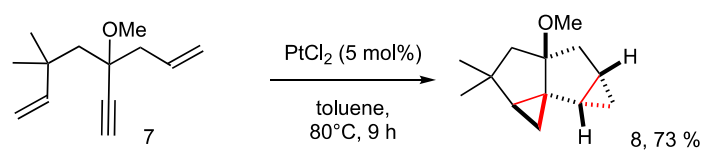<smiles>C#CC(CC=C)(COC)CC(C)(C)C=C</smiles><smiles>C#CC(CC=C)(CC(C)(C)C=C)OC(C)=O</smiles><smiles>[M]CC([R1])(C#CC)OC(C)=O</smiles>

Scheme 3 Ether $v s$ ester dichotomy in the $\mathrm{PtCl}_{2}$-catalyzed cycloisomerization of dienynes

We exploited this transformation towards an expeditious synthesis of [3.1.0]bicyclic cyclopropylketones such as sabina ketone, from easily prepared 1,5-enyne 11.27 This natural product is a key precursor of monoterpenes such as sabinene. A formal mechanism would involve platinacarbene of type D (Pt-D) that is trapped by the exo-methylene motif to generate the corresponding polycyclic cyclopropylvinylacetate $\mathbf{1 2}$ as a single diastereomer. One has to say "formal" since a total chirality transfer was observed by Füstner from the exactly the same precursor with $\mathrm{AuCl}_{3}$ (pyridine), ${ }^{26 \mathrm{~b}}$ suggesting a more concerted type of mechanisms in all these transformations. After saponification, the desired sabina ketone was isolated in 83\% yield over these two steps (Scheme 4).

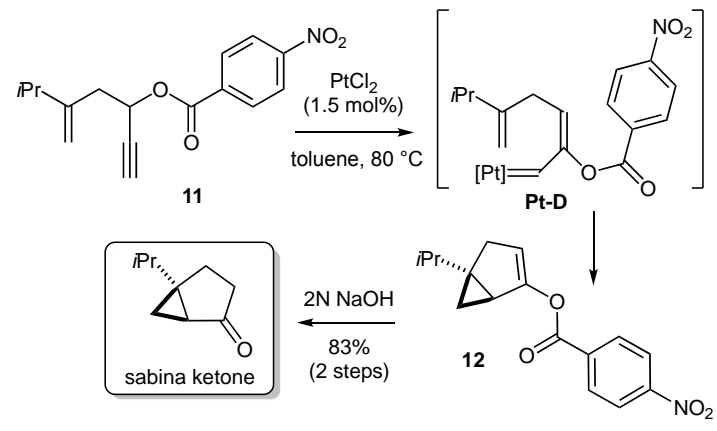

Scheme 4 Total synthesis of sabina ketone

Moving from platinum(II) to gold(I) revealed a more efficient and general way to generate molecular complexity which has been highlighted in several total syntheses in various families of natural products. ${ }^{28} \mathrm{We}$ exploited the gold catalyzed 1,2-O-acyl transposition/trapping sequence towards neomerane sesquiterpenes skeletons. Sesquiterpenes are an important class of natural products as they are found in plants and insects, acting as semiochemicals. ${ }^{29}$ Two targets attracted more specifically our attention, namely neomeranol and valeneomerin B. Neomeranol $\mathbf{1 3}$ is a brominated sesquiterpene alcohol which was isolated from the green alga Neomeris annulata. Besides its attractive structure of marine halogenated metabolite, neomeranol shows phytotoxicity to johnsongrass and toxicity to brine shrimp. ${ }^{30}$ More recently, Mother Nature offered another surprise since the related neomerane-type sesquiterpenoid valeneomerin B $\mathbf{1 4}$ was isolated in continental surroundings from the roots of Valeriana officinalis var. latifolia. ${ }^{31}$ For centuries, this plant has been used in Chinese medicine for the treatment of insomnia. To date, no total synthesis of these two sesquiterpenoids has been described.

We surmised that a substrate bearing a propargyl acetate function as a carbene precursor as well as a prenyl acceptor could lead to the common 5,7,3-fused ring skeleton in one step by platinum- or gold-catalyzed 1,2-acyloxy migration/intramolecular cyclopropanation sequence.25a Starting from 6-methyl-5-hepten-2-one and thanks to highly diastereoselective steps, precursor $\mathbf{1 5}$ was efficiently obtained in seven steps. While $\mathrm{PtCl}_{2}$ failed to give any cycloisomerization product, Echavarren's cationic gold(I) complex [Au1] proved to be the most effective in this transformation and led to the expected tricycle $\mathbf{1 6}$ in 70\% yield as a single diastereoisomer, probably through the vinyl gold carbene intermediate of type $\mathbf{D}$ (Au-D). Liberation of an enolate intermediate by MeLi followed by trapping by iodomethane or formaldehyde provided the desired skeletons. Better yields were obtained in the latter case which drove us to valeneomerin B family. After desilylation and diastereoselective reduction, triol $\mathbf{1 7}$ was obtained in $32 \%$ overall yield which could be acetylated to access 5-epivaleneomerin B. ${ }^{32}$ 

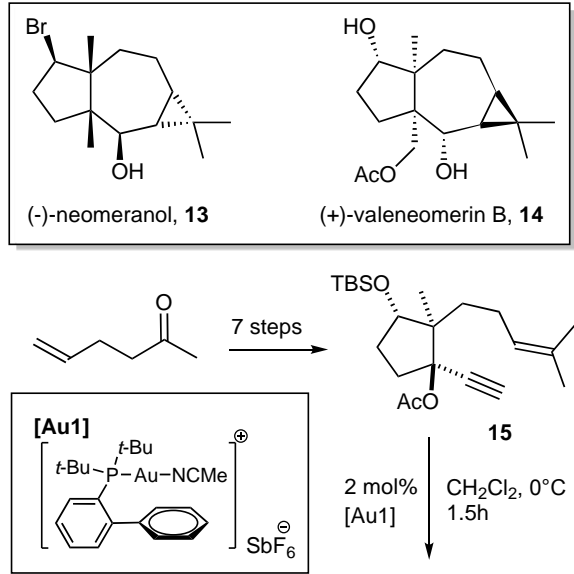

TBSO
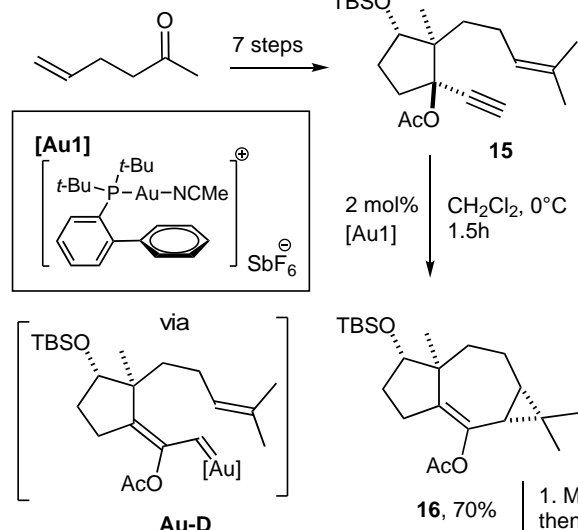

TBSO

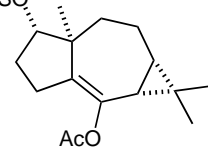

16, 70\% $\mid \begin{aligned} & \text { 1. MeLi, } \mathrm{ZnCl}_{2} \\ & \text { then }\left(\mathrm{CH}_{2} \mathrm{O}\right) \mathrm{n}\end{aligned}$

2. TBAF
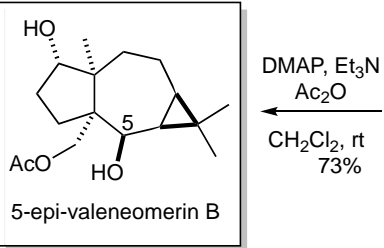

$\mathrm{HO}$ 3. $\mathrm{LiAlH}_{4}$

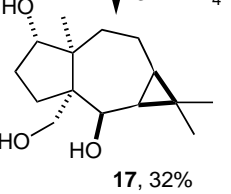

Scheme 5. Total synthesis of 5-epi-valeneomerin B

While the 1,2-O-acyl migration - carbene formation proved to be a very good trigger for a series of intramolecular events, we also examined intermolecular trappings as first described by Ohe and Uemura. ${ }^{33}$ Notably, we developed a new polymerization process by polycyclopropanations ${ }^{34}$ of styryl propargyl acetates. ${ }^{35}$ In collaboration with the Ryu's group in Osaka, we also considered the possibility to incorporate $\mathrm{CO}$ into the Rautenstrauch rearrangement. ${ }^{36}$ While the platinum and gold carbene intermediate complexes D could not trap CO, rhodium(I) catalysis proved to be the right option. Thus, under CO-atmosphere, a Rh-catalyzed $O$-acyl-transposition can lead to a subsequent cyclocarbonylation to afford formal [4+1] or $[5+1]$ products, depending on the alkyne substituent on precursors 18 (Scheme 6). Disubstituted alkynes $\left(R^{1} \neq H\right)$ lead to exo-Z-cyclopentenones 19 as major diastereoisomers while terminal alkynes $\left(\mathrm{R}^{1}=\mathrm{H}\right)$ gave resorcinol derivatives 21 . In the first case, 1,3-O-acyl migration, as we will also see later, leads to rhodacyclopentenes $\mathbf{E}$, which insert $\mathrm{CO}$ to give $\mathbf{1 9}$. In contrast, after 1,2-O-acyl migration, intermediates of type D (Rh-D) insert CO to give ketenes $\mathbf{2 0}$ that undergo electrocyclization to provide valuable resorcinols $\mathbf{2 1}$.

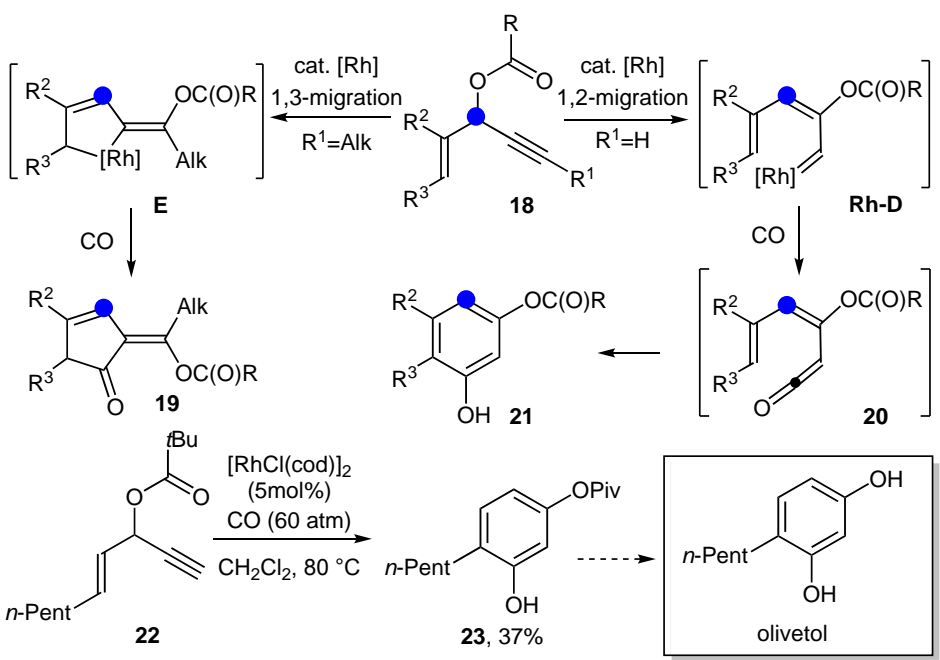

Scheme 6. Carbonylative Rautenstrauch rearrangement via Rh catalysis

For instance, enyne $\mathbf{2 2}$ gave $\mathbf{2 3}$ in $37 \%$ yield (along with noncarbonylated cyclopentenone), which is an ester derivative of the natural product olivetol. Olivetol ${ }^{37}$ is an extract of lichen and a precursor of tetrahydrocannabinol (THC). It is secreted by some insects, either as a pheromone, a repellent or an antiseptic.

Allenes were obvious substrates to submit to electrophilic catalysis and we focused on vinyl allenes substrates of type 24 flanked with a pendant alkene group. ${ }^{38}$ We demonstrated that the central allene moiety can be activated by gold, leading to allylic cation or bent allene intermediate 25, ${ }^{39}$ that triggers a Nazarov-type cyclization. The generated gold cyclopentenylidene intermediate $\mathbf{2 6}$ is then trapped by the second olefin present, leading to tricyclic derivatives of type $\mathbf{2 7}$ (Scheme 7). ${ }^{40}$

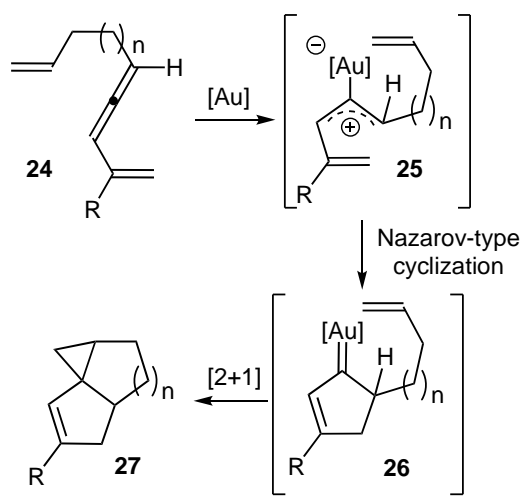

Scheme 7. Tricyclic derivatives via a gold cyclopentenylidene intermediate

Further scope of this process was based on the straightforward formation of allenyl esters from propargyl acetates of disubstituted alkynes through a platinum or a gold-catalyzed 1,3-O-acyl migration. ${ }^{41}$ We applied this allene generation/cyclization/carbene interception sequence to the efficient total synthesis of $\Delta^{9(12)}$ capnellene. This linear triquinane natural product is a marine sesquiterpene of the capnellane family, isolated from Capnella imbricata. ${ }^{29}$ In this approach, we thus 
synthesized the tricyclopentanoid framework in a single step, from enyl acetate precursor $\mathbf{2 8}$ (obtained in five steps from cyclopentane dione), with complete stereoselectivity. By using cationic Echavarren's catalyst [Au1], 1,3-O-acyl transposition occurred, delivering in situ the complexeed allenyl acetate 29a of interest. The latter underwent the expected Nazarov-type cyclization, leading to auracarbene 29c that was intercepted by the olefin at $\delta$-position to create the cyclopropyl moiety. After hydrolysis, the corresponding cyclopropylketone $\mathbf{3 0}$ was isolated in $85 \%$ yield. Subsequent functional modifications included the ketone reduction followed by cyclopropane regioselective platinum catalyzed hydrogenolysis and Barton-McCombie deoxygenation to give 31. Further desilylation, Dess-Martin periodinane oxidation and classical Wittig olefination with a phosphorus ylide led in three steps to the targeted $\Delta^{9(12)}$ capnellene (Scheme 8). ${ }^{42}$

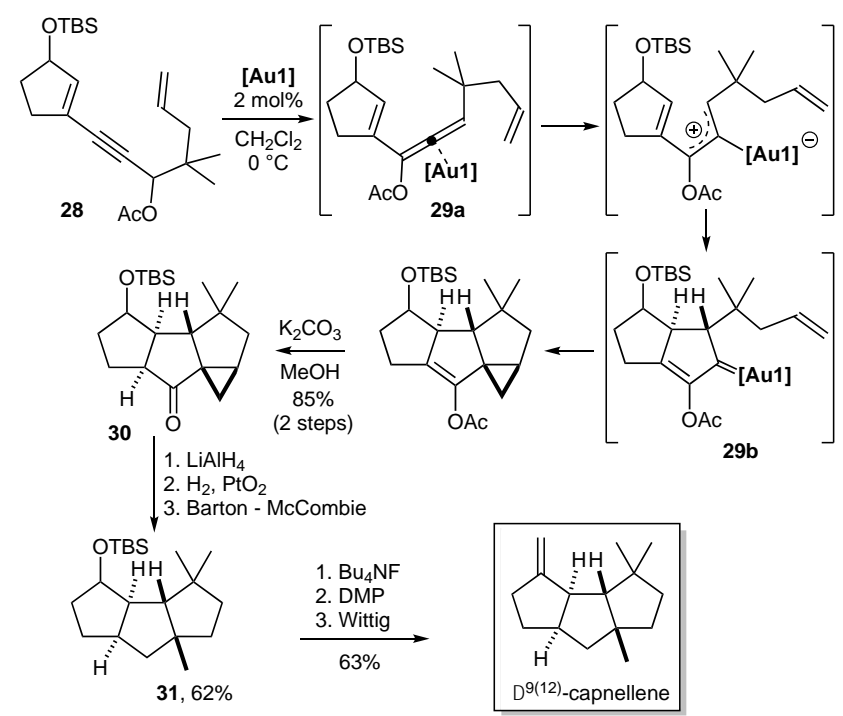

Scheme 8. Total synthesis of $\Delta^{9(12)}$-capnellene via vinylallene cycloisomerization

\section{From alkylidene bis(sulfoxides) to chiral carboxylic acids}

In a context of total synthesis, methodology towards obtaining enantiopure products is of utmost importance. Diastereoselective synthesis is one of the major techniques within asymmetric catalysis and racemate separation to access optically active compounds. In this context, we studied the synthesis ${ }^{43}$ and the reactivity of chiral alkylidene bis(sulfoxydes) $\mathbf{3 2}^{44}$ as chiral Michael acceptors in radical ${ }^{45}$ and ionic processes. ${ }^{46,47}$

For examples, various neutral or anionic nucleophiles can be stereoselectively introduced by conjugate addition. Indeed, after optimization of the reaction conditions, we showed that amines, alcoolates and dimethylmalonate led to the $(S)$-adducts of type 33 in excellent diastereomeric ratios. Cyclopropane formation $((S)-34)$ is also possible by using sodium bromomalonate as nucleophile: concomitant nucleophilic substitution occurs to afford the corresponding pentasubstituted cyclopropane. By using diethylzinc, a small erosion of the selectivity was observed, probably due to involvement of competitive chelate, and $(S)$-33d was obtained in 88/12 diastereoisomeric ratio
(84\%). Finally, the use of cuprate reagents ${ }^{45 b}$ allowed to selectively obtain the opposite $(R)$-adduct $(R)$-33e (Scheme 9). 46

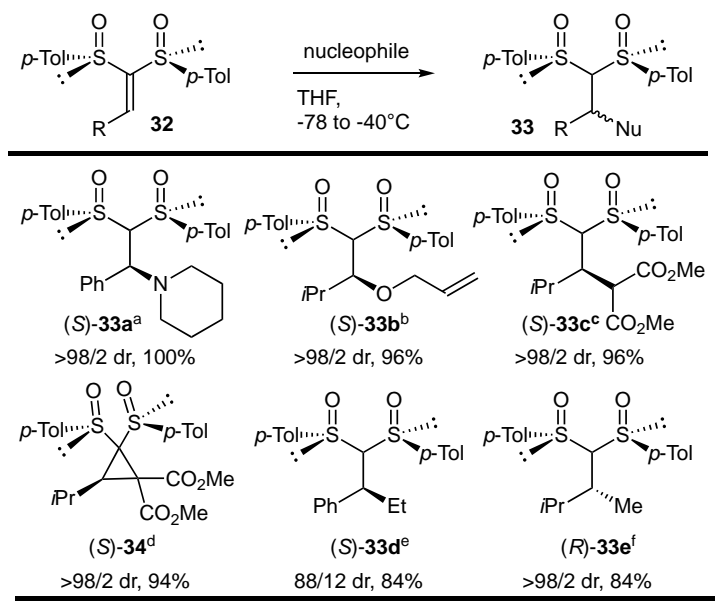

Nucleophile $=\left(\right.$ a) piperidine. (b) $\mathrm{NaOCH}_{2} \mathrm{CH}=\mathrm{CH}_{2}$. (c) $\left(\mathrm{CO}_{2} \mathrm{Me}\right)_{2} \mathrm{CNa}$

(d) $\left(\mathrm{CO}_{2} \mathrm{Me}\right)_{2} \mathrm{CBr}^{-}, \mathrm{Na}^{+}$(e) $\mathrm{Et}_{2} \mathrm{Zn}$. (f) $\mathrm{MeLi}(2 \mathrm{eq}), \mathrm{CuI}$

Scheme 9. Examples of highly diastereoselective conjugate addition to alkylydene bis(sulfoxides) 32

The diastereoselectivity outcome of the addition process was rationalized based on the examination of the $\mathrm{X}$-ray structure of alkylidene bis(sulfoxides) and notably 32a $(\mathrm{R}=\mathrm{Ph})$. The latter discloses a tolyl-tolyl $\pi$-stacking interaction (3.53 $\AA$ between centroids). It also shows that the lone pair of one of the sulfynyl group quasi-eclipses the alkene substituent R. Moreover, one can notice a hydrogen bonding between the oxygen of the other sulfynyl group and the vinylic hydrogen atom in $\beta$-position ( $d=2.28 \AA$ ) which results in minimization of allylic strain. Assuming a similar preferred conformation of type $\mathbf{F}$ in solution, which is also consistent with conformational calculations of vinyl sulfoxides, ${ }^{48}$ the $p$-tolyl substituents would hinder the alkene $R e$ face and thus direct the nucleophilic attack on the $S i$ face to give the corresponding $(S)$-adduct. In the presence of cuprate reagents like methyl cuprate, chelates of high complexity, as suggested by calculations, ${ }^{45 \mathrm{~b}}$ are probably involved to give rise to the $(R)$-adduct (Scheme 10).

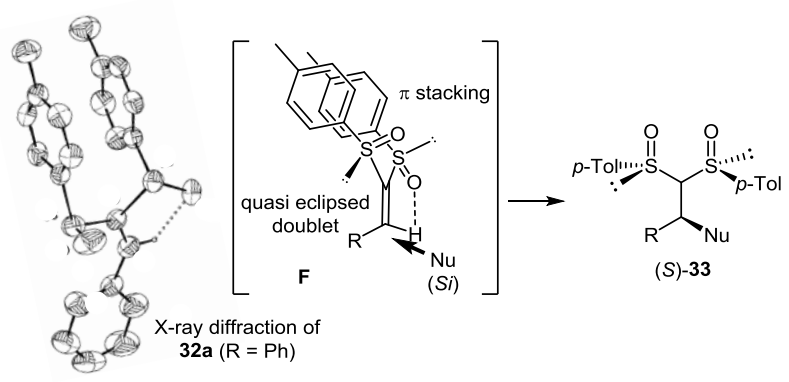

Scheme 10. Suggested reactive conformation 
A valuable feature of a bis(sulfinyl) moiety is that it can be transformed into a carboxylic derivative through a Pummerer type of rearrangement. ${ }^{44}$ We applied this methodology to the total synthesis of optically enriched $\alpha$-substituted carboxylic acids profens, which is most important group of nonsteroidal anti-inflammatory drugs. Although they are prescribed as a racemic mixture, there is indeed a constant interest in obtaining them in the enantioenriched form. In spite of the fact that $(S)$ profens are generally accepted to be the bioactive enantiomers, knowing the pharmaceutical profile of the $(R)$ derivatives is essential. ${ }^{49}$ When styryl bis(sulfoxide) $32 \mathrm{f}$ was treated by methyl lithium (2 eq) in the presence of copper iodide, the expected adduct $(R)$-33f was isolated quantitatively as a single diastereoisomer. Subsequent treatment with trifluoroacetic anhydride in the presence of pyridine and saponification led to enantiomerically pure $(R)$-fenoprofen in $40 \%$ yield (Scheme 11). ${ }^{46,50}$

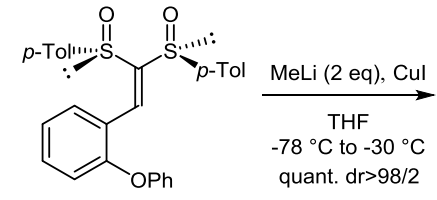

$32 f$<smiles>C[C@H](C(=O)O)c1ccccc1Oc1ccccc1</smiles>

$(R)$-fenoprofen

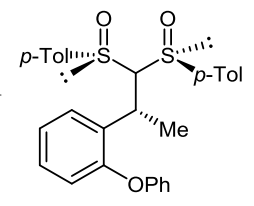

$(R)-33 \mathbf{f}$

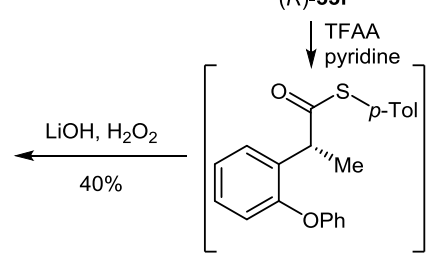

Scheme 11. Synthesis of $(R)$-fenoprofen

Introduction of a second controlled stereocenter during this conjugate addition stage was then considered and applied to the first total synthesis of optically enriched (+)-roccellic acid. This trans-diacid was isolated in 1994 from Lichens, 51 and no asymmetric synthesis had been reported. ${ }^{52}$ It possesses amongst others an interesting antituberculosis activity. ${ }^{53}$

Based on Heathcock's work, ${ }^{54}(E)$-enolate 35 was formed by deprotonation of a propionic ester with LDA. It was then added to alkylidene $\mathbf{3 2} \mathbf{g}$ bearing a $\mathrm{C}_{15}$-alkyl side-chain and the antiadduct was logically obtained as the major product. The approach F1 rationalizing this stereochemical outcome minimizes the steric hindrance by opposing the methyl substituent and the alkyl side-chain. Anti-33g was formed in $90 / 10 \mathrm{dr}$ and cleanly isolated in 79\% yield. As precedently, Pummerer reaction and saponification led to the targeted natural product $(+)$-roccellic acid that was isolated in $50 \%$ (Scheme 12). ${ }^{46}$

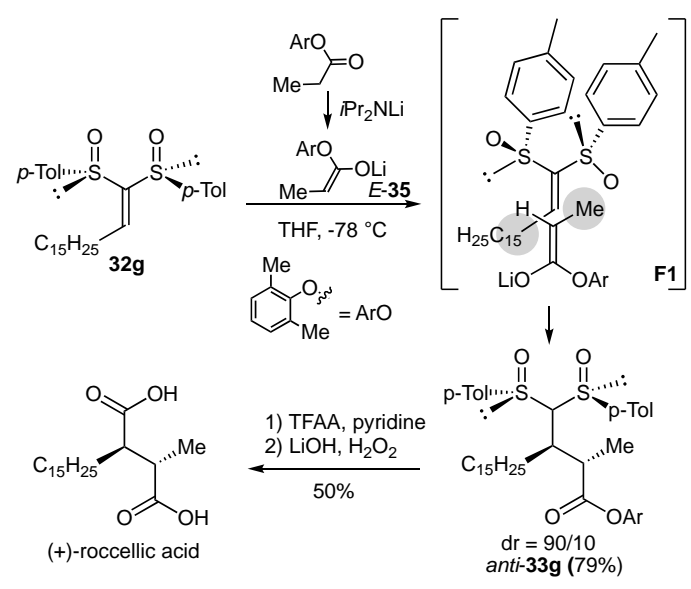

Scheme 12. Total synthesis of (+)-roccellic acid

Respective synthesis of the syn diastereoisomer was also envisioned and we targeted optically enriched syn-sphaeric acid. Isolated in 1999 from fermentation of broth of Sphaeropsis sp., 55 it displays an interesting antibiotic activity against Staphylococcus aureus and Bacillus subtilis, and interacts with interleukine-1 that is involved in the immune system.

However, when the corresponding Z-enolates Z-35 or Z-36 were used, even if the face-selectivity of the addition onto the alkylidene was total, the undesired anti-adduct was obtained as the major diastereoisomer. This lack of diastereoselectivity can be explained by the dissociative effect of HMPA used to generate the Z-enolate, OLi becomes less sterically demanding, so the differentiation between $\mathrm{OLi}$ and $\mathrm{O} t \mathrm{Bu}$ is weaker than without HMPA. So, the slightly favored transition state F3 preventing the steric interaction between the methyl substituent and the alkylidene alkene side chain and leading to the anti product is in competition with transition state F2 giving the desired cis isomer. By using a large excess of HMPA and higher temperature $\left(-20^{\circ} \mathrm{C}\right)$, both diastereoisomers were obtained in an almost $1 / 1$ ratio, providing synthetically useful quantities of syn-33h adduct (30\%). Total synthesis of (+)-sphaeric acid was successfully completed after double saponification. The first one relied on the previously described Pummerer/LiOH- $\mathrm{H}_{2} \mathrm{O}_{2} \mathrm{n}$ sequence. But a TMSCl/NaI treatment was necessary to cleave the tert-butyl ester (15\% overall). ${ }^{56}$ It is worthy to note that absolute configuration of (+)-sphaeric acid was established for the first time through this total synthesis.

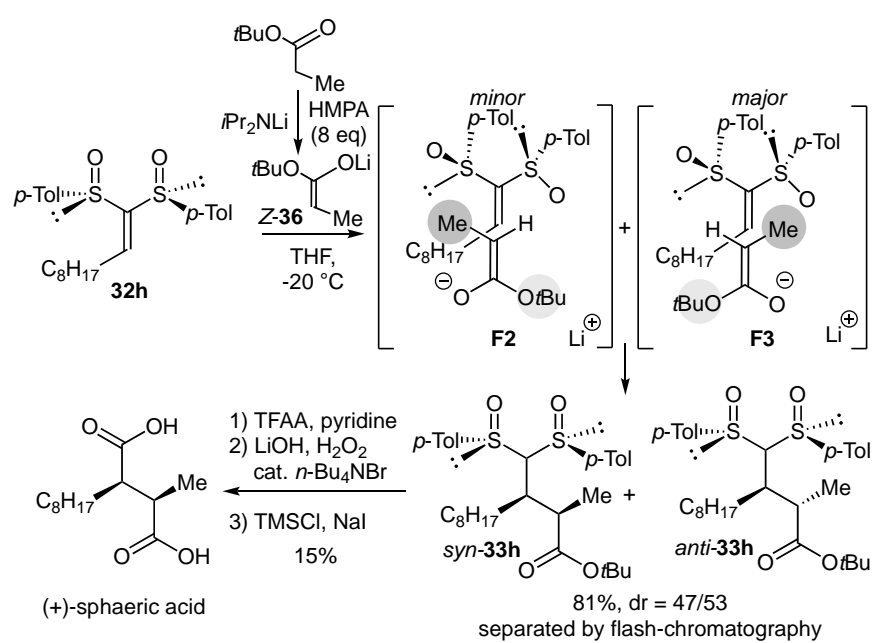

Scheme 13. Total synthesis of (+)-sphaeric acid 


\section{Conclusion and perspectives}

In conclusion, this journey has highlighted several methodologies, radical cascades, electrophilic catalysis and bissulfoxide chemistry which bear as common feature the possibility to rapidly access molecular complexity from readily available precursors. This has allowed to assemble various types of natural products (acyclic, heterocyclic and polycyclic). Our next efforts in this area consist in the development of new catalytic processes, notably photoredox or photosentisized cascades, as well as dual catalysis sequences. We have recently evidenced the high synthetic potential embodied in this type of approaches. $^{57}$

\section{Acknowledgment}

We feel very grateful to all the coworkers from our group and from collaborative networks who have participated to these efforts and who co-authored all the cited papers. Special thanks also to Max Malacria and to our colleagues "permanents" associated to these works: Christine Courillon, Etienne Derat, Anne-Lise Dhimane, Vincent Gandon, JeanPhilippe Goddard, Emmanuel Lacôte, Virginie Mouriès-Mansuy and Cyril Ollivier We also thank UPMC, CNRS, ANR, Labex MiChem and IUF for financial support as well as technical assistance offered by FR 2769.

References

(1) (a) Rychlet Elliott, M.; Dhimane, A.-L.; Malacria, M. J. Am. Chem. Soc. 1997, 119, 3427. (b) Devin, P.; Fensterbank, L.; Malacria, M. J. Org. Chem. 1998, 63, 6764. (c) Bogen, S.; Gulea, M.; Fensterbank, L.; Malacria, M. J. Org. Chem. 1999, 64, 4920.

(2) Beaume, A.; Courillon, C.; Derat, E.; Malacria, M. Chem. Eur. J. 2008, $14,1238$.

(3) For a review on the use of $\mathrm{N}$-cyanamides in synthesis, see: Larraufie, M.-H.; Maestri, G.; Malacria, M.; Ollivier, C.; Fensterbank, L.; Lacôte, E. Synthesis 2012, 44, 1279.

(4) (a) Larraufie, M.-H.; Ollivier, C.; Fensterbank, L.; Malacria, M.; Lacôte, E. Angew. Chem. Int. Ed. 2010, 49, 2178; (b) Larraufie, M.-H.; Courillon, C.; Ollivier, C.; Lacôte, E.; Malacria, M.; Fensterbank, L. J. Am. Chem. Soc. 2010, 132, 4381.

(5) Amin, A. H.; Mehta, D. R. Nature 1959, 183, 1317.

(6) Al-Shamma, A.; Drake, S.; Flynn, D. L.; Mitscher, L. A.; Park, Y. H.; Rao, G. S. R.; Simpson, A.; Swayze, J. K.; Veysoglu, T.; Wu, S. T. S. J. Nat. Prod. 1981, 44, 745 .

(7) Johns, S. R.; Lamberton, J. A. J. Chem. Soc., Chem. Commun. 1965, 267. (8) (a) Hart, N. K.; Johns, S. R.; Lamberton, J. A. Aust. J. Chem. 1971, 24, 223. (b) Liu, J. F.; Wilson, C. J.; Ye, P.; Sprague, K.; Sargent, K.; Si, Y.; Beletsky, G.; Yohannes, D.; Ng, S. C. Bioorg. Med. Chem. Lett. 2006, 16, 686.

(9) (a) See ref. 4b. (b) Beckwith, A. L. J.; Bowry, V. W.; Bowman, W. R.; Mann, E.; Parr, J.; Storey, J. M. D. Angew. Chem. Int. Ed. 2004, 43, 95.

(10) Schiesser, C. H. Chem. Commun. 2006, 4055.

(11) (a) Coulomb, J.; Certal, V.; Fensterbank, L.; Lacôte, E.; Malacria, M. Angew. Chem. Int. Ed. 2006, 45, 633. (b) Coulomb, J.; Certal, V.; Larraufie, M.-H.; Ollivier, C.; Corbet, J.-P.; Mignani, G.; Fensterbank, L.; Lacôte, E.; Malacria, M. Chem.Eur. J. 2009, 15, 10225.

(12) Smith, G. M. T.; Burton, P. M.; Bray, C. D. Angew. Chem. Int. Ed. 2015 $54,15236$.

(13) (a) Ojasoo, T.; Dore, J. C.; Gilbert, J.; Raynaud, J.-P. J. Med. Chem. 1988, 31, 1160. (b) Smil, D. V.; Souza, F. E. S.; Fallis, A. D. Bioorg. Med. Chem. Lett. 2005, 15, 2057.

(14) C. Starkenmann, Y. Niclass, I. Cayeux, R. Brauchli, A.-C. Gagnon, Flavour Frag. J. 2015, 30, 91.

(15) N. Jubran, A. R. Katritzky, J. V. Ugro, Jr., Patent W09745273, 1997.

(16) Kyne, S. H.; Aitken, H. M.; Schiesser, C.; Lacote, E.; Malacria, M.; Ollivier, C.; Fensterbank, L. Org. Biomol. Chem. 2011, 9, 3331.
(17) (a) Chatani, N.; Furukawa, N.; Sakura, H.; Murai, S. Organometallics 1996, 15, 901. (b) Fürstner, A.; Szillat, H.; Gabor, B.; Mynott, R. J. Am. Chem. Soc. 1998, 120, 8305. (c) Mendez, M.; Munoz, M. P.; Nevado, C.; Cardenas, D. J.; Echavarren, A. M. J. Am. Chem. Soc. 2001, 123, 10511. (d) Charruault, L.; Michelet, V.; Taras, R.; Gladiali, S.; Genet, J.-P. Chem. Commun. 2004, 850.

(18) (a) Hashmi, A. S. K.; Frost, T. M.; Bats, J. W. J. Am. Chem. Soc. 2000, 122, 11553. (b) Nieto-Oberhuber, C.; Paz Muñoz, M.; Buñuel, E.; Nevado, C.; Caŕdenas,D. J.; Echavarren, A.M. Angew. Chem., Int. Ed. 2004, 43, 2402. (c) Mamane, V.; Gress, T.; Krause, H.; Fürstner, A. J. Am. Chem. Soc. 2004, 126, 8654. (d) Luzung, M. R.; Markham, J. P.; Toste, F. D. J. Am. Chem. Soc. 2004, 126, 10858 .

(19) For reviews, see: (a) Fürstner, A. Chem. Soc. Rev. 2009, 38, 3208. (b) Fensterbank, L.; Malacria, M. Acc. Chem. Res. 2014, 47, 953. (c) Dorel, R.; Echavarren, A. M. Chem. Rev. 2015, 115, 9028.

(20) (a) Mainetti, E.; Mouriès, V.; Fensterbank, L.; Malacria, M.; MarcoContelles, J. Angew. Chem. Int. Ed. 2002, 41, 2132. (b) Marco-Contelles, J.; Arroyo, N.; Anjum, S.; Mainetti, E.; Marion, N.; Cariou, K.; Lemière, G.; Mouriès, V.; Fensterbank, L.; Malacria, M. Eur. J. Org. Chem. 2006, 4618.

(21) Chatani, N.; Kataoka, K.; Murai, S.; Furukawa, N.; Seki, Y. J. Am. Chem. Soc. 1998, 120, 9104.

(22) (a) Mendez, M.; Munoz, M. P.; Nevado, C.; Cardenas, D. J.; Echavarren, A. M. J. Am. Chem. Soc. 2001, 123, 10511. (b) Soriano, E.; Ballesteros, P.; Marco-Contelles, J. Organometallics 2005, 24, 3172. (c) Witham, C. A.; Mauleon, P.; Shapiro, N. D.; Sherry, B. D.; Toste, F. D. J. Am. Chem. Soc. 2007, 129, 5838.

(23) For seminal reports on 1,2- $O$ acyl transposition, see: (a) Rautenstrauch, V. J. Org. Chem. 1984, 49, 950. (b) Strickler, H.; Davis, J. B.; Ohloff, G. Helv. Chim. Acta 1976, 59, 1328.

(24) For reviews dealing with propargyl acetate transposition, see: (a) Marion, N.;, S. P. Angew. Chem. Int. Ed. 2007, 46, 2750. (b) J. MarcoContelles, E. Soriano, Chem. Eur. J. 2007, 13, 1350. (c) Shu, X.-Z.; Shu, D.; Schienebeck, C. M.; Tang, W. Chem. Soc. Rev. 2012, 41, 7698. (d) Wang, S.; Zhang, G.; Zhang, L. Synlett 2010, 692. (e) Shiroodi, R. K.; Gevorgyan, V.; Chem. Soc. Rev. 2013, 42, 4991. (f) Fensterbank, L.; Goddard, J.-P.; Malacria, M.; Simonneau, A. in Homogenous Gold Catalysis, Michelet, V.; Toste, D., Eds.; Imperial College Press London 2014, 331.

(25) For representative contributions from our group, see: (a) Moreau, X.; Goddard, J.-P.; Bernard, M.; Lemière, G.; Lopez-Romero, J. M.; Mainetti, E.; Marion, N.; Mouriès, V.; Thorimbert, S.; Fensterbank, L.; Malacria, M. Adv. Synth. Catal. 2008, 350, 43. (b) Harrak, Y.; Makhlouf, M.; Azzaro, S.; Mainetti, E.; Lopez Romero, J. M.; Cariou, K.; Gandon, V.; Goddard, J.-P.; Malacria, M.; Fensterbank, L. J. Organometallic Chem. 2011, 696, 388.

(26) (a) Marion, N.; Lemière, G.; Correa, A.; Ramon, R. S.; Moreau, X.; de Frémont, P.; Dahmane, R.; Hours, A.; Lesage, D.; Tabet, J.-C.; Goddard, J.P.; Gandon, V.; Cavallo, L.; Fensterbank, L.; Malacria, M.; Nolan, S. P. Chem. Eur. J. 2009, 15, 3243. See also: (b) Shi, X.; Gorin, D. J.; Toste, F. D. J. Am. Chem. Soc. 2005, 127, 5802. (c) Nieto Faza, O.; Carlos Silva Lopez, C.; Alvarez, R.; de Lera, A. R. J. Am. Chem. Soc. 2006, 128, 2434. (d) Fürstner, A.; Hannen, P. Chem. Eur. J. 2006, 12, 3006. (e) Fehr, C.; Galindo, J. Angew. Chem., Int. Ed. 2006, 45, 2901

(27) (a) Harrak, Y.; Blaszykowski, C.; Bernard, M.; Cariou, K.; Mainetti, E.; Mouriès, V.; Dhimane, A.-L.; Fensterbank, L.; Malacria, M. J. Am. Chem. Soc. 2004, 126, 8656. (b) For a golden asymmetric version, see: Fürstner, A.; Schlecker, A. Chem. Eur. J. 2008, 14, 9181.

(28) For reviews on gold catalysis in natural products synthesis: (a) Rudolph, M.; Hashmi, A. S. K. Chem. Soc. Rev., 2012, 41, 2448. (b) Pflästerer, D.; Hashmi, A. S. K. Chem. Soc. Rev., 2016, 45, 1331. (c) Quach, R.; Furkert, D. P., Brimble, M. A. Org. Biomol. Chem., 2017, 15, 3098. (d) Stathakis, C. I.; Gzikis, P. L.; Zografos, Z. L. Nat. Prod. Rev. 2016, 33, 1093. For some recent contributions: (d) Qiu, Y.; Zhou, J.; Fu, C.; Ma, S. Chem. Eur. J., 2014, 20, 14589. (e) Carreras, J.; Livendahl, M.; McGonigal, P. R.; Echavarren, A. M. Angew. Chem. Int. Ed., 2014, 53, 4896. (f) Bellavance, G.; Barriault, L. Angew. Chem., Int. Ed., 2014, 53, 6701. (g) Liu, Y.; Zhou, C.-J.; Li, Q.; Wang, H. Org. Biomol. Chem., 2016, 14, 10362. (h) Kirillova, M. S.; Muratore, M. E.; Dorel, R.; Echavarren, A. M. J. Am. Chem. Soc., 2016, 138, 3671. (i) Dorel, R.; Echavarren, A. M. J. Org. Chem. 2016, 81, 8444. (j) Pflästerer, D.; Rudolph, M.; Yates, B. F.; Ariafard, A.; Hashmi, A. S. K. Adv. Synth. Catal. 2017, 359, 866. (k) McGee, P.; Bétournay, G.; Barabé, F.; 
Barriault, L. Angew. Chem. Int. Ed., 2017, 56, 6280. (l) Bai, Y.; Shen, X.; Li, Y.; Dai, M. J. Am. Chem. Soc. 2016, 138, 10838. (m) Vulovic, B.; Kolarski, D.; Bihelovic, F.; Matovic, R.; Gruden, M.; Saisic, R. N. Org. Lett. 2016, 18 , 3886. correction: Org. Lett. 2016, 18, 5186.

(29) Le Bideau, F.; Kousara, M.; Chen, L.; Wie, L.; Dumas, F. Chem. Rev. 2017, 117, 6110 .

(30) (a) Barnekow, D. E.; Cardellina II, J. H.; Zektzer, A. S.; Martin, G. E. J. Am. Chem. Soc., 1989, 111, 3511. (b) Paul, V. J.; Cronan, J. M. Jr.; Cardellina II, J. H. J. Chem. Ecol., 1993, 19, 1847. (c) Barnekow, D. E.; Cardellina II, J. H. Tetrahedron Lett., 1989, 30, 3629.

(31) Han, Z.-Z.; Zu, X.-P.; Wang, J.-X.; Li, H.-L.; Chen, B.-Y.; Liu, Q.-X.; Hu, X.Q.; Yan, Z.-H.; Zhang, W.-D. Tetrahedron, 2014, 70, 962.

(32) Tugny, C.; Khaled, O.; Derat, E.; Goddard, J.-P.; Mouriès-Mansuy, V.; Fensterbank, L. Org. Chem. Front. 2017, 4, 1906.

(33) (a) Miki, K.; Ohe, K.; Uemura, S. Tetrahedron Lett. 2003, 44, 2019. (b) Miki, K.; Ohe, K.; Uemura, S. J. Org. Chem. 2003, 68, 8505. (c) Johansoon, M. J.; Gorin, D. J.; Staben, S. T.; Toste, F. D. J. Am. Chem. Soc. 2005, 127, 18002.

(34) For a similar approach, see: Miki, K.; Washitake, Y.; Ohe, K.; Uemura, S. Angew. Chem. Int. Ed. 2004, 43, 1857.

(35) Nzulu, F.; Bontemps, A.; Robert, J.; Barbazanges, M.; Fensterbank, L.; Goddard, J.-P.; Malacria, M.; Ollivier, C.; Petit, M.; Rieger, J.; Stoffelbach, F. Macromolecules 2014, 47, 6652.

(36) (a) Brancour, C.; Fukuyama, T.; Ohta, Y.; Ryu, I.; Dhimane, A.-L.; Fensterbank, L.; Malacria, M. Chem. Commun. 2010, 5470. (b) Fukuyama, T.; Ohta, Y.; Brancour, B.; Miyagawa, K.; Ryu, I.; Dhimane, A.-L.; Fensterbank, L.; Malacria, M. Chem. Eur. J. 2012 18, 7243.

(37) Raharjo, T. J.; Chang, W.-T.; Choi, Y. H.; Peltenburg-Looman, A. M. G.; Verpoorte, R. Plant Sci., 2004, 166, 381.

(38) For similar approaches, see: (a) Lee, J. H.; Toste, F. D. Angew. Chem., Int. Ed. 2007, 46, 912. (b) Funami, H.; Kusama, H.; Iwasawa, N. Angew. Chem., Int. Ed. 2007, 46, 909. (c) Zhang, L.; Wang, S. J. Am. Chem. Soc. 2006, 128, 1442.

(39) Gandon, V.; Lemière, G.; Hours, A.; Fensterbank, L.; Malacria, M. Angew. Chem. Int. Ed. 2008, 47, 7534.

(40) Lemière, G.; Gandon, V.; Cariou, K.; Fukuyama, T.; Dhimane, A.-L.; Fensterbank, L.; Malacria, M. Org. Lett., 2007, 9, 2207.

(41) (a) Cadran, N.; Cariou, K.; Hervé, G.; Aubert, C.; Fensterbank, L.; Malacria, M.; Marco-Contelles, J. J. Am. Chem. Soc. 2004, 126, 3408. (b) Cariou, K.; E. Mainetti, E.; Fensterbank, L.; Malacria, M. Tetrahedron 2004, 60, 9745.

(42) Lemière, G.; Gandon, V.; Cariou, K.; Hours, A.; Fukuyama, T.; Dhimane, A.-L.; Fensterbank, L.; Malacria, M. J. Am. Chem. Soc. 2009, 131, 2993.

(43) (a) Delouvrié, B.; Nájera, F.; Fensterbank, L.; Malacria, M. J. Organomet. Chem. 2002, 643-644, 130. (b) Brebion, F.; Goddard, J.-P.; Fensterbank, L.; Malacria, M. Synthesis 2005, 2449.
(44) For a review on bis(sulfoxydes), see: Delouvrié, B.; Fensterbank, L.; Nájera, F.; Malacria, M. Eur. J. Org. Chem.2002, 3507.

(45) (a) Brebion, F.; Vitale, M.; Fensterbank, L.; Malacria, M. Tetrahedron: Asym. 2003, 14, 2889. Calculation assessed that the metallic species involved is a cuprate rather than a copper reagent, see: (b) Brebion, F.; Vincent, G.; Chelli, S.; Kwasnieski, O.; Nájera, F.; Delouvrié, B.; Marek, I.; Derat, E.; Goddard, J.-P.; Malacria, M.; Fensterbank, L. Chem., Asian J. 2011, 6, 1825.

(46) Brebion, F.; Delouvrié, B.; Nájera, F.; Fensterbank, L.; Malacria, M.; Vaissermann, J. Angew. Chem. Int. Ed. 2003, 42, 5342.

(47) (a) Goddard, J.-P.; Gomez, C.; Brebion, F.; Beauviere, S.; Fensterbank, L.; Malacria, M. Chem. Commun. 2007, 2929. (b) Abramovitch, A.; Fensterbank, L.; Malacria, M.; Marek, I. Angew. Chem. Int. Ed. 2008, 47, 6865.

(48) (a) L. F. Tietze, A. Schuffenhauer, P. R. Schreiner, J. Am. Chem. Soc. 1998, 120, 7952. For similar directing effect of the sulfinyl moiety, see also: (b) G. Sklute, I. Marek, J. Am. Chem. Soc. 2006, 128, 4642. (c) Kahn, D.; Hehre, W. J. J. Am. Chem. Soc. 1986, 108, 7399.

(49) Giacomini, D.; Galletti, P. Innovation in Pharmaceutical Technology 2008, 78 .

(50) For reviews on fenoprofen pharmaceutical activity, see: (a) Traa, M. X.; Derry, S.; Moore, R. A., Cochrane Database Syst Rev. 2011, CD007556. (b) Gruber, C. M. J. Rheumatology 1976, 3, 8.

(51) (a) The Merck Index, 12th Edition, 1996, article 8405; (b) Huneck, S.; Schmidt, J.; Porzel, A. Z. Naturforsch. B 1994, 49, 561, and references therein.

(52) For the racemic synthesis, see: (a) Mangaleswaran, S.; Argade, N. P.; J. Chem. Soc. Perkin Trans. 1, 2001, 1764. (b) De Buyck, L.; Danieli, C.; Ghelfi, F.; Pagnoni, U. M.; Parsons, A. F.; Pattarozzi, M.; Roncaglia, F. Tetrahedron, 2005, 61, 2871.

(53) Barry, V. C.; Belton, J. G.; Kelly, R. M.; Twomey, D. Nature 1950, 166, 303. (b) Pereira, F. M.; de Sa, J.; Bhatnagar, S. S. Indian J. Pharm. 1953, 15 287.

(54) Heathcock, C. H.; Pirrung, M. C.; Montgomery, S. H.; Lampe, J. Tetrahedron 1981, 37, 4087.

(55) Wilkinson, R. A.; Strobel, G.; Stierle, A. J. Nat. Prod. 1999, 62, 358.

(56) Brebion, F.; Goddard, J.-P.; Gomez, C.; Fensterbank, L.; Malacria, M. Synlett 2006, 713.

(57) (a) Goddard, J.-P.; Ollivier, C.; Fensterbank, L. Acc. Chem. Res. 2016, 49, 1924; (b) C. Lévêque, V. Corcé, L. Chenneberg, C. Ollivier, L. Fensterbank, Eur. J. Org. Chem. 2017, 2118; (c) Z. Xia, O. Khaled, V. Mouriès-Mansuy, C. Ollivier, L. Fensterbank, J. Org. Chem. 2016, 81, 7182.

\section{Biosketches}

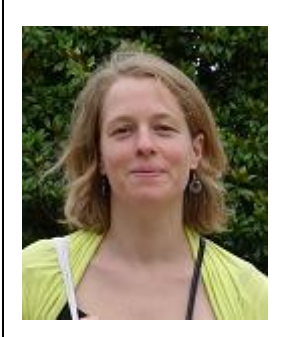

Marion Barbazanges was born in Annecy, France, in 1981. From 2001 to 2005, she studied at the Ecole Supérieure de Physiques et de Chimie Industrielle de la ville de Paris (ESPCI Paris). In 2005, she received the M. Sc. in Chemical Science and Engineering of ESPCI, as well as the M. Sc. in Organic and Bioorganic Chemistry of the Université Pierre et Marie Curie (Paris, France). She joined Pr. Cossy's lab for her Master degree and her PhD, where she worked on enamides' sigmatropic rearrangement as well as total synthesis of amphidinolide J. After a post-doctoral stay in Pr. A.G.M. Barrett's group in Imperial College, London (2009), she joined Dr. C. Aubert and Pr. L. Fensterbank lab as a post-doctoral fellow (2010) then as an assistant lecturer (since 2011), working on organometallic chemistry and chirality. 


\begin{tabular}{|l|l|}
\hline & $\begin{array}{l}\text { Louis Fensterbank was born in Poitiers in } 1967 \text { and raised in Tours. He graduated from Ecole } \\
\text { Supérieure de Chimie Industrielle de Lyon (ESCIL) in } 1990 \text { and ob tained his Ph.D. on silicon- } \\
\text { tethered reactions in } 1993 \text { at SUNY Stony Brook under the supervision of Scott Sieburth. After a } \\
\text { tempo rary lecturer position at UPMC in 1994, he was appointed in 1995 Chargé de Recherche } \\
\text { CNRS in Max Malacria's team. In 2004, he ob tained a professorship position at UPMC and, in } \\
\text { 2008, he was nominated junior member at the Institut Universitaire de France. His research } \\
\text { interests concern the discovery of new molecular transformations relying on radical or } \\
\text { organometallic processes and their applications to the synthesis of substrates with relevant } \\
\text { properties (e.g., natural products, probes, ligands). He serves in the editorial board of Organic } \\
\text { Chemistry Frontiers. Recently, he received the Prix de la Division de Chimie Organique of the } \\
\text { French Chemical Society (2016) and the Silver Medal from CNRS (2017) and was elected Fellow of } \\
\text { the Royal Society of Chemistry (2016). }\end{array}$ \\
\hline
\end{tabular}

